\title{
Acting for the Local Community: Hybrid Ethnography in the Careers of Local Culture Animators
}

\author{
Rafał Wiśniewski \\ Cardinal Stefan Wyszyński University in Warsaw \\ National Centre for Culture, Poland
}

Grażyna Pol

National Centre for Culture, Poland

DOI: https://doi.org/10.18778/1733-8069.17.3.09

Keywords: culture animator, diary method, hybrid ethnography, spatial analysis, social role, career

\begin{abstract}
This article focuses on the innovative methodology used to collect data. We describe how we have utilized the diary method and what analytical potential it contains. We also flag the limitations we have perceived during the research. At the same time, so as not to refrain entirely from a discussion of the study findings, we recreate selected shared attributes in the careers of culture animators. A hybrid research method was used to report and interpret the reality of our surroundings. This involved the use of a diary in which the animators described facts and events from the previous day while also plotting data concerning their location on the Google map; they enriched their notes with short essays, pictures, and video clips. Then, the animators as subjects in the research took part in one-on-one indepth interviews to summarize their experience. Deliberations on the utility and innovativeness of these ethnographic methods are accompanied by considerations as to the variety of experience held by culture animators and the factors driving their occupational choices.
\end{abstract}

Rafał Wiśniewski, sociologist, cultural manager; Director of the National Centre for Culture, professor at the Cardinal Stefan Wyszyński University in Warsaw; does research and publishes on the sociology of culture and intercultural communication.

\section{Contact details:}

Cardinal Stefan Wyszyński University in Warsaw

ul. Wóycickiego 1/3, 01-938 Warsaw

email address: r.wisniewski@uksw.edu.pl
Grażyna Pol, graduate of sociology at the University of Warsaw; Deputy Director of the Department of Research and Analysis at the National Centre for Culture. The author's research interests focus on the methodology of social sciences and the sociology of culture.

\section{Contact details:}

National Centre for Culture

ul. Płocka 13 01-231 Warsaw

email address: gpol@nck.pl 


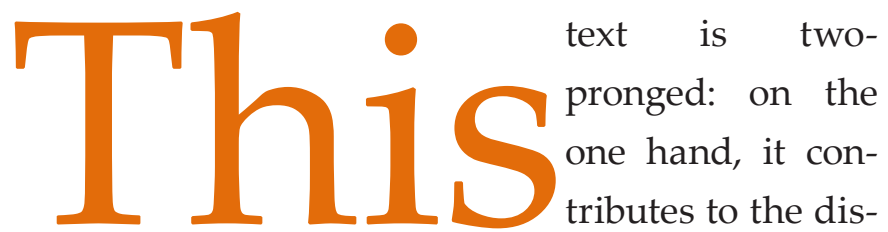
cussion on the possible applications of hybrid ethnography; on the other hand, it advances an opinion in the debate surrounding the factors shaping the careers of culture animators. ${ }^{1}$ It serves both of these functions while referencing the data obtained as part of the comprehensive research on local-government cultural centers. ${ }^{2}$ Local-government institutions of culture that frequently provide space for the activity of animators play a special role in local communities: they develop a feeling of community and accountability for shared matters, they build an awareness of causation, and they shape the competences required to participate actively in a civic society. The research discussed in this article responds to the need for more extensive research into

\footnotetext{
1 In its original meaning, animation denotes 'initiating action'. The word comes from Latin: anima - 'soul', animatio - 'enliven', and animare - 'enlive, give life to something'. In turn, we as the authors will understand the type of animation that is of particular interest to us - namely cultural animation - as follows: first, creating conditions in which people - individuals and groups - can satisfy their needs as part of culture which they discover or find on their own. "The goal of animatory activity conceived of in this manner is, therefore, not in any way to be understood as the dissemination of the so-called "high culture" or the most valuable products of mass culture; [...] Here the fundamental frame of reference is the entirety of a person's cultural potentiality, the entirety of his or her cultural personality" (Godlewski et al. 2002:64). In turn, an animator is a person who inspires others to discover their own potential, an inspirer or initiator; a person who 'raises interest in something, who encourages'. He or she is a person who has the capacity of apprehending the problems encountered by a given community and responding to them in a skillful manner. The local activities initiated by such a person also stimulate mechanisms that are characteristic of a civic society.

${ }^{2}$ This research was launched and funded by the National Centre for Culture. The subject matter of the research involves the functions discharged by cultural centers: starting with the ones that are stricte related to culture, to those concentrated on the local social capital, including local institutions involved in building the community and, as a consequence, a civic society.
}

the environment of social workers. "There is a need to engage in more extensive research into the community involved in non-profit activity than to date. This type of research will make it possible, in our opinion, to obtain knowledge about the 'morphology' of the Polish civic society while also possibly becoming a component of the collective identity of activists involved in non-governmental activity (Nowosielski and Nowak 2008).

Local leadership is also included among the local resources capable of strengthening the mechanisms of a civic society on top of the strong bonds linking members of the community or the community's access to personal and material means. The latter element is directly associated with the activity of culture animators, because the terms "cultural leader and "culture animator" frequently have an overlapping meaning. ${ }^{3}$ For this reason, the tasks of a leader in the context of local cultural activity can in practical terms be treated as tantamount to being that type of activity which is also ascribed to a culture animator. With this convergence in terms of their definitions and meaning in mind, we made the decision during the research to link leaders and culture animators, and treat them as people fulfilling the very same function.

\footnotetext{
3 As Magdalena Dudkiewicz and Marek Dudkiewicz have observed, "Leaders of culture deliberately 'create culture' in their local environment which constitutes their natural backdrop and strengthens the force of their impact having regard for the possibility of effecting factual (conceptual, mental, educational, social) change and fulfilling the postulate of local adjustment, chiefly through discovering and taking advantage of local cultural resources" (Dudkiewicz and Dudkiewicz 2017:4). When defining a culture animator in her lexicon entitled Stownik Teorii Żywej Kultury [The Lexicon of the Theories on Living Culture], Barbara Fatyga states as follows: "The distinctiveness of an animator's charisma stems from his or her authority, whose requisite constituent element is the skill of being able to withdraw into the shadow when the animatory activities start to accrue results" (2014).
} 
The purpose of this article is to present an innovative methodology enriched by a reflection on the advantages and imperfections of the adopted solutions. For these deliberations to be fully graspable, the text includes a reference to analyses in order to recreate the characteristic elements of the activity of local culture animators and map their activity. The research questions focused on two issues. The first one pertains to the advantages and disadvantages of the presented methodology. The second one concerns the activity of culture animators. It investigates issues related to what inspires and motivates them to work for the benefit of the local community. It also concerns spatial analyses, namely the locations and the conditions in which animators carry out the duties entrusted to them. The portrait of the prosocial activity of local culture animators reconstructed in this manner has been used to ponder on their professional position.

Multiple scientific texts have been published on the careers of selected occupational groups ${ }^{4}$; for this reason, we will not focus on analyzing this term. We would merely like to emphasize that we understand a career to denote the vocational path of a person, in particular during those periods of life when that person is professionally active (see Domecka and Mrozowicki 2008). As Howard S. Becker and James Carper (1956) have observed, the notion of a career can be examined twofold: an objective aspect related to promotions within an employee hierarchy or the role of a given person in an organization, as well as a subjective aspect related to how an individual per-

${ }^{4}$ The concept of a career in an interactionist sense pertains to its objective aspects (Goffman 1961) as well as the subjective ones (Hughes 1958; Goffman 1961). Krzysztof Konecki (1988), Markieta Domecka and Adam Mrozowicki (2008), as well as Ewa Krause (2012) were among the Polish researchers who have made contributions to the body of theory regarding this subject matter. ceives the situation in which he/she is placed, and to what extent this situation is consistent with his/her expectations. In this article, we have concentrated on the subjective perception of a career path, because the compiled material shows many similar elements in the interlocutors' narratives. We devoted the sub-section IV to the shared components of their activity.

Recognizing the activity of animators in terms of professional activity does not exhaust the subject. The tasks of a leader are identified with stimulating mechanisms that are characteristic of a civic society: “According to Max Weber's well-known division, a culture animator is a calling and - let us add - a social role, not a professional role. It is also possible to use Weberian inspiration by characterizing a culture animator as a special type of charismatic leader in a local community or group" (Fatyga 2014). In the case of the persons taking part in the research under scrutiny, this special type of charisma appears to ensue from their multiple competences and positive work ethics.

The next section is devoted to the applied research techniques and the strategy for selecting the individuals to participate in the research into local culture animators.

\section{The methodological framework of the project}

This research consisted of four modules, namely one based on quantitative techniques and three based on qualitative techniques, as has been portrayed in detail in Table 1. For the purposes of this text, we distinguished between the material collected during the diary research and the one-on-one in-depth interviews conducted with local culture animators to summarize the said material (see row 3 in Table 1). 
Table 1. Modules of the comprehensive research into cultural centers in Poland

\begin{tabular}{|c|c|c|}
\hline No. & Technique & $\begin{array}{l}\text { Sample size and information } \\
\text { regarding the participants/ } \\
\text { respondents }\end{array}$ \\
\hline 1 & $\begin{array}{c}\text { Mixed Mode Sur- } \\
\text { vey Design } \\
\text { CAWI, CATI, } \\
\text { CAPI } \\
\text { nationwide sam- } \\
\text { ple of cultural } \\
\text { centers in Poland }\end{array}$ & $\begin{array}{l}\mathrm{N}=1076 \\
\text { interviews with the directors and } \\
\text { employees of cultural centers } \\
\text { with the greatest amount of work } \\
\text { seniority and the most extensive } \\
\text { knowledge about the operation of } \\
\text { their institution }\end{array}$ \\
\hline 2 & IDI & $\begin{array}{l}40 \text { interviews with represen- } \\
\text { tatives of institutions from the } \\
\text { environment of the cultural cen- } \\
\text { ters: schools, non-governmental } \\
\text { organizations, offices of the com- } \\
\text { munes and parishes; } \\
3 \text { interviews and } 1 \text { short poll (brief } \\
\text { conversation in a public spot), } \\
\text { completed with the representa- } \\
\text { tives of a school, non-governmen- } \\
\text { tal organization, office of a com- } \\
\text { mune, and a parish in a commune } \\
\text { in which there is no cultural center } \\
\text { in operation }\end{array}$ \\
\hline 3 & $\begin{array}{l}\text { Diary research } \\
\text { (7 days) with ele- } \\
\text { ments of ethnog- } \\
\text { raphy and IDIs to } \\
\text { summarize }\end{array}$ & $\begin{array}{l}6 \text { interviews with local culture } \\
\text { animators, with the use of the dia- } \\
\text { ry method }\end{array}$ \\
\hline 4 & FGI online & $\begin{array}{l}2 \text { focus group interviews with the } \\
\text { directors of cultural centers (10 par- } \\
\text { ticipants in total) }\end{array}$ \\
\hline
\end{tabular}

Source: Wiśniewski et al. 2021

Before we conducted the diary research, it had been necessary to pick the animators. The research procedure consisted of several stages. Above all, communes were picked. The starting point was the analysis concerning the activity of communes ${ }^{5}$ and

\footnotetext{
${ }^{5}$ Data of the Local Data Bank pertaining to the cultural activity of local government entities in 2017.
}

their spendings on culture. ${ }^{6}$ We defined the cultural activity of a commune as the total sum of artistic groups, events, affiliations, and clubs per resident, while the expenditures - as the budget per resident. Then, we employed the following rule by assigning communes to six different ranges:

1. Activity 1. Quartile and Budget 1. Quartile $\rightarrow$ (1) low activity and low budget;

2. Activity 1. Quartile and Budget 4. Quartile $\rightarrow$ (2) low activity and high budget;

3. Activity 4. Quartile and Budget 1. Quartile $\rightarrow$ (3) high activity and low budget;

4. Activity 4. Quartile and Budget 4. Quartile $\rightarrow$ (4) high activity and high budget;

5. Activity 2 or 3. Quartile and/or Budget 2 or 3. Quartile $\rightarrow$ (5) other;

6. No data available in the category Activity and/or Budget $\rightarrow(6)$ no data available.

On the basis of the table of values for the above two variables, communes were selected from the first and fourth quartiles having regard for their characteristic ratio of expenditures incurred for cultural activity to the cultural offer accessible in those communes. This made it possible to identify communes under the following schematic: (1) low activity and low budget $(n=3)$; (2) low activity and high budget $(n=2)$; (3) high activity and low budget $(\mathrm{n}=2)$; (4) high activity and high

\footnotetext{
${ }^{6}$ Data pertaining to the income and expenditures in the budgets of local government entities in 2017. At the stage of designing the research, these were the most recent full records of annual data available.
} 
budget $(n=3){ }^{7}$ The schematic for selection has been presented in Figure 1. The tentative analysis of the information regarding communes' expenditures and activities made us realize that on top of communes reporting their activity to the Statistics Poland there is also a group of entities whose budgetary data and number of cultural events organized in their areas are unavailable. We considered that to be an indicator of how differently those communes conduct their cultural activity. This is also why we selected one commune on top of the previously chosen ten local government entities; it had not furnished information about its activity and expenditures, and in its territory there is no local state cultural center. Therefore, category (6) was formed on account of the absence of information on activity and budget, and the lack of a cultural center within the territorial limits of the commune $(n=1)$.

\section{Figure 1. The visualization of the selection of communes}

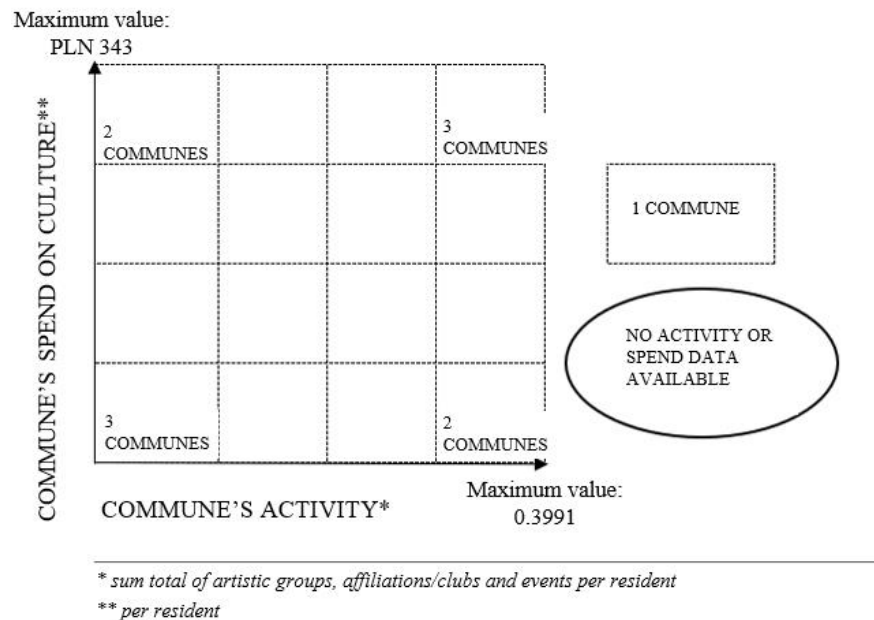

Source: Wiśniewski et al. 2021

\footnotetext{
${ }^{7}$ The inspiration for utilizing this split came from the analyses conducted by the Institute for Educational Research under the BECKER Project (Research into the economic determinants for the goals and targets of allocating capital expenditures to education pursued by public and private entities in Poland). See http://eduentuzjasci.pl/becker.html.
}

After selecting the communes, one-on-one in-depth interviews (IDIs) were held with the representatives of schools, non-governmental organizations, the offices of communes and parishes, or the entities that undertake cultural activities in the confines of the very same administrative unit as the studied cultural centers. We recruited people to participate in the ethnographic research from among the leaders discovered during the analysis of the data originating from the qualitative research (IDI) in a given commune. ${ }^{8}$ We posited that a person we intended to recognize as being a local leader should be mentioned in at least one of the four one-on-one in-depth interviews conducted in the territory of a single commune. We conducted a diary measurement with one animator from each type of commune distinguished from among the 11 communes selected for participation in the research: (1), (2), (3), (4), and (6). The participants of the interviews in one of the selected communes failed to identify any local leader, while in a different commune they listed several of them.

We chose to employ diary research on account of the ability it provides to observe animators during their daily activities. This method also facilitates the recording of contents at the time they appear naturally, and the persons can share their observations over a longer period of time. In such instances, some researchers

\footnotetext{
${ }^{8}$ The research team made this identification on the basis of recordings or transcripts of individual in-depth interviews. In the interview script, the body of the question was worded as follows: "In your community or in its closest vicinity, is there a person who exerts a significant influence on culture and the local community? I am thinking about a person (not about an institution) who gathers others around him or her and who has clout. A person who initiates and co-organizes many cultural events in your parts. Are you capable of identifying someone like that? Perhaps, there is more than one such person who acts as an animator of cultural life? Please tell me why you consider this person or persons to be a leader or leaders? [If no spontaneous response is given, one might ask about local activists, well-known people associated with the region and acting to the benefit the local community, artists, celebrities]." In reality, the wording of the question could have slightly deviated from the adopted template.
} 
stress the significance of participatory research (Stage, Eriksson, and Reestorf 2019). Changes in technology and people's attitudes have meant that the set of skills needed to run modern field research has undergone transformation, because it calls for developed digital competences, including IT skills (operating hardware and software) and information-related skills (searching for content, selecting content, and critical evaluation). Internet ethnography is one of the newly-formed research techniques. Some studies suggest that it is a type of a shortcut to obtain multiple-source data, but thinking about ethnography as using the Internet as a certain shortcut or facility can evidence that the essence of the issue has not been perceived correctly (Kozinets 2006). This type of research method is part of hybrid ethnography. According to Liz Przybylski (2020), hybrid ethnography ${ }^{9}$ should be understood as a researcher's work with the interviewee' multiple sources of expression that have various distinctive attributes and which the researcher must interpret to grasp the meaning conveyed by the participants (see Seim 2019).

The research reconstructed in this article contains elements of the hybrid approach. We chose to utilize the classic method of structured diaries, which entailed the animator writing down their activities related to a chosen type of activity in a specially designed questionnaire. ${ }^{10}$ Additionally, however, the participant

\footnotetext{
${ }^{9}$ Many areas of life, especially those that are related to expressive culture, exist in both digital and physical space. Liz Przybylski's book abounds with pragmatic hints on how to prepare, run, and analyze ethnographic research situated in a hybrid field reality. Special emphasis is placed here on media and the visual layer, including images and sound as elements constituting an inseparable part of modern research into the culture of expression.

${ }^{10}$ Over a period of seven days, the respondents copiously documented the events from this period. During the research, they described their observations, feelings, and thoughts related to the method of organization and execution of cultural events held in their nearest vicinity. They also documented their contacts with the representatives of institutions of culture, communes, schools, parishes, and non-governmental organizations, as well as their informal relations with the residents of
}

supplemented this information on the performed activities by taking pictures or noting his/her location on the map. The entirety of the data was placed on an Internet platform devoted to this research. ${ }^{11}$ The one-on-one in-depth interviews with the aim of summarizing the work crowned the measurement. The multimedia structure of the diary contributed to the comfort and freedom of the participants who selected the time, the venue, and the breadth of what they wanted to convey. This also gave them the possibility to construe a narrative utilizing media and streamline the data collection process whereby they could upload those materials onto the server immediately after compiling them. The multimedia aspect made the process attractive and may have inspired the participants to portray phenomena or events which they would not have had an opportunity to reference in a classic qualitative interview (Pink 2008).

Utilizing a visual message helps one understand and illustrate the practices of the person without having to give extensive explanations thereof (Gibson et al. 2013). We perceive that as an advantage, because an image replete with the respondent's commentary potentially provides more information than the very same description, even if it is highly detailed. Another undeniable advantage of the diary method is also the immediate capturing of the person's events, thoughts, or observations at the time when they occur, which minimizes the possibility of distortions related to retrospection. Similarly to any other method, this one does have certain inherent limitations, including the most important one, namely that keeping a diary may affect the interviewee's behavior, as he/she mod-

the same community/commune. Every day, the subjects filled out several fundamental information sheets with regard to the people with whom they spent their time, what they did, and where they had been. Additionally, every day they received one task calling for more work.

${ }^{11}$ See: https://softarchitect.pl/flyblog. 
ifies that behavior and endorses socially acceptable attitudes or portrays himself/herself in a better light. Moreover, the researcher can hardly control the conscientiousness with which the participants perform their assignments (for example, the researcher can merely verify whether a research participant performs the assignments every day or whether he/she does that belatedly). Since the researcher has few tools to check whether the person reports all of the activities performed in an accurate manner, this method does require the research participants to demonstrate a lot of commitment. For this reason, many actions need to be taken to minimize the time intensity. Above all, the structured questionnaire must be duly designed to limit the number of questions recurring every day, as well as the more demanding open questions. For the greater comfort of the participants, one should always give consideration to shortening the number of the days of measurement, as well as the option to participate in the research through a mobile app or a special online platform (Laughland and Kvavilashvili 2018).

The Polish tradition of research diaries extends back to the first half of the 20th century, when Józef Chałasiński and Bronisław Malinowski were performing their work. ${ }^{12}$ At present, the diary method is going through a renaissance and is inscribed in the broader stream of research focused on the relativistic notion of reality. In this project to adjust the structure of the diaries to the distinct nature of the group under research, and also to align this project with research trends, the diaries kept for the purpose of this research of ours were uploaded onto a platform for online research (Online Bulletin Board). Therefore, the research participants could complete them in a virtual form, which made it possible to write down opinions and report them on an ongoing basis in any place and time, thus par-

\footnotetext{
$\overline{{ }^{12} \text { See Malinowski }} 2007$.
}

ticipating in social processes. This also enabled the respondents to add photos with captions and record short video clips containing their commentary. The researchers were observing the entries appearing in the diaries on an ongoing basis, as well as they remarked on the uploaded material and posed questions. This made it possible to gain a better grasp on the areas under scrutiny.

The hybrid nature of ethnography creates an opportunity to employ the diary method in order to secure a number of digital materials (photos, ${ }^{13}$

\footnotetext{
${ }^{13}$ The research participants took pictures during special assignments which formed a part of the diary method. One of these assignments involved illustrating regular activities which the person usually performed every day. In the second assignment, in turn, the participant assumed the role of an ambassador for the local community and was supposed to tell a stranger about the local community. The instructions were as follows:

I. "Please take several photos to illustrate five regular things you usually do during the day. Please prepare captions for the photos and tell us why these rituals are important to you."

II. "Today we would like for you to start telling us about the local community's life. Your assignment is to play the role of an ambassador for your local community and tell a traveler about that community. Please provide thorough answers to the following questions and document your story with several photos:

1. What does your local community mean to you?

2. How would you describe your local community? Please characterize it in several sentences.

3. How long have you lived here? What kind of people live in your near surroundings? How well do you know your neighbors and other residents of the community? What is the important thing for you in neighborly relations? How frequently do you meet with other residents of the community? Under what circumstances? What do you do when you meet? What do you talk about?

4. How are you involved in the activities of the local community? Why do you devote your time to the local community affairs? What have you managed to accomplish recently? What would you like to brag about?

5 . How much of your private time do you devote to actions for the local community?

6. What gives you the greatest pleasure when you are involved in local activities? What causes you the greatest difficulty?

7. Which institutions' representatives do you have contact with the most frequently? Why exactly do you have contact with them?

8. In your opinion, which institutions are the most important to the development of your community? What makes them so important? What type of undertakings do they carry out? Which of them appear to you to be the most interesting and the most beneficial from the viewpoint of the local community?"
} 
video clips, ${ }^{14}$ and GPS locations) as well as blend the secured data with information coming from the individual in-depth interviews. The participants used the diary research chiefly to recount events and memories. During the measurement that lasted seven days, ${ }^{15}$ the animators reported all of the activities they performed and the locations where they were (imposing the coordinates on the Google map), as well as they estimated the duration of the various tasks and identified the persons accompanying them during the day. Moreover, they performed several additional tasks, for the completion of which more time was anticipated (2-3 days), as each one of them was a non-recurring task. ${ }^{16}$ After the completion of the diary research, one-hour-long one-on-one in-depth interviews were held with the persons, ${ }^{17}$ during which the contents of the diary were summarized and follow-up questions were posed concerning the material obtained through them. This conversation added themes compiled during the interviews with other peoples from a given local community, enriching them with the perspective brought by the animators. It also offered

\footnotetext{
${ }^{14} \mathrm{On}$ account of its modest share and form (self-presentation of the subject), the video clip has not been included in the analyses presented in this article.

${ }^{15}$ In research techniques requiring greater involvement - and there is no doubt that the diary method is one of them - what appears to be key is: 1. maintaining (for the full length of the measurement period) the greatest number of persons who have elected to participate in the measurement; and 2. maintaining the motivation of the people to work with the tool with commitment. In the described project, the decision was made to collect data for seven full days, as this time period makes it possible to fulfill the two foregoing conditions, and additionally capture the person' routine activities.

${ }^{16}$ Some of these assignments have already been mentioned in footnote no. 13. The animators were also asked to report a local event (especially a cultural one) that had taken place during the week covered by the measurement.

${ }^{17}$ Representatives of the company doing business as 'Danae' conducted the conversations, as the business is responsible for running the entire project under the name of 'Comprehensive Research into Cultural Centers in Poland', including the research modules described in this article.
}

the opportunity to verify the researcher's original interpretations.

\section{Common elements in the actions of local animators}

As was already mentioned, we have observed several recurring patterns of activity in the interviews and the diaries. What appears to be important in the description of the animators' careers is the category embodying the motivation to act for the benefit of the local community, involving the assumption that certain personality traits of an individual (disinterest, resourcefulness, communicativeness, kindness, and diligence) - combined with specific determinants in this person's surroundings - direct that person to become engaged in animation activities. We identified situations in which there are numerous and active non-governmental organizations in a commune under study, or in which there is a rich local cultural heritage (particular valuable historical monuments or natural assets, etc.) and deemed them favorable. Access to infrastructure enhancing the attractiveness of animation activities can provide support, as can the relatively high financial means of a commune, making it possible to focus activity on animation activities:

This is very work-intensive and very much engages the employees of the cultural center [statement concerning one of the activities of cultural centers - R.W.], but I believe it is worth it, because that is the purpose we serve. [A2]

Another similarity is activity in many areas of life and not restricting activity to one selected local organization, but multi-pronged activity for the entire local community: 
In my local community, I organize events jointly with the $\mathrm{KGW}^{18}$ and the OSP, ${ }^{19}$ e.g. Mother's Day, Women's Day, Grandmother and Grandfather's Day, Carnival, Caroling, Spring Day, Easter Egg Meetings, Christmas Eve Meetings, craftsmanship workshops (e.g. weaving an Easter palm, the art of decorating with macaroni, decoupage, and paper baskets). Our community also gets involved in various social campaigns: 'Renovating Saint Florian's Chapel', 'Driver for Jakub', 'Give your heart to a single mother', 'Collection for flood victims from the [name] commune', 'Collection for fire victims in [name of the commune]'. There is no shortage of celebrations such as the Jubilee Days of the KGW and the Celebration of Firefighters' Day. Nor is there a shortage of matrimonial gates, building altars for Corpus Christi, or cleanup in and around the Saint Florian's Chapel. [A6]

\section{The extensive network of informal contacts with} local decision-makers, civil servants, directors of local cultural institutions, city council members, and business owners is an accompanying element. The rule of reciprocity ${ }^{20}$ (Cialdini 1995) also plays a significant role in forming a contact network. Animators amass social capital by providing support in the form of their knowledge and creativity to the organizers of various events. The bond created in this manner is sometimes utilized by animators when they organize subsequent undertakings:

Since I have always been involved in local matters and I taught in school, I met many people in town and have good contacts with them. Nor do I have any difficulty with neighborly relations, though they are not very close. Nevertheless, I can count on their [the neighbors - R.W.] assistance in need (and vice versa). [A2]

\footnotetext{
18 'Koło Gospodyń Wiejskich' ['Rural Women's Group']. 19 'Ochotnicza Straż Pożarna' ['Voluntary Fire Brigade']. ${ }^{20}$ See the social exchange theory according to Peter Blau (1964) and George Homans (1967).
}

The network of people favorable to the interviewees is being build steadily, but it does not constitute an end in itself. The desire to get animators involved in many local affairs testified to their multiple competences and their personality traits:

[...] a few neighbors were in attendance and they said to me: [first name], you will do it the best. You handle it. [...] There is no common room, this is missing, that is missing. How would you see that? [...] There are also [...] many different pieces of advice. Some of them are strange and have nothing in common with culture [...]. Our MGOPS [Urban Commune Social Aid Center R.W. $]^{21}$ frequently calls me: 'there is this lady - what do you think about how we can help her?' [A5]

The statements of the research participants simultaneously allude to the fact that even though they are active people, they do not have a sense of great control over their professional choices. Their social activity is sometimes dictated by their feeling of internal emptiness, while their activities to benefit the local community are a way for them to fill that emptiness.

[...] Perhaps you have to have that something to [feel that - R.W.] something was lacking. In that manner, however, for that to affect their work, their commitment, their dedication, to how they devote their time, on how they treat that way of living, for there is certainly no financial dimension, for there are many [such moments - R.W.] that you have to give something from yourself, also when it comes to financial affairs, to dedicate your own devices, not to mention time [...]. [A5]

When reporting their involvement in the cultural activity of their own children, on the one hand the research participants expressed their concerns, especial-

${ }^{21}$ Urban Commune Social Aid Center. 
ly when referring to the financial sphere. On the other hand, their words indicated that they had a sense of pride in the fact that they have managed to inculcatesin them the positive work ethos of a local leader, ${ }^{22}$ characterized by his/her work commitment, especially the work done to benefit the local community.

Some of the animators also talked with great reverence and commitment about the local activity of their ancestors. They talked about how - as successors of ideas and accomplishments in the field of their relatives' social activity - they feel an obligation to continue their work, or at least disseminate knowledge about their creativity. Above all, however, one can speak about the intergenerational inheritance of social activity:

The Regional Team [name] was established in 1966 as part of the KGW ${ }^{23}$ [community - R.W.] by my grandmother: [first and last name]. [...] On the basis of relations with persons born before 1900, my grandmother wrote the screenplay for [name of the play] containing rituals, melodies, and typical songs from the area of [name of the community] and the surrounding villages. This program has won many highly-regarded awards at various folklore reviews. [...] Purveying the Regional Team's archives gives me the opportunity to learn more about my grandmother's work and inspires me to continue working with the Regional Team. My grandmother [first and last name, date of birth and death] was a social activist; she organized various contests for women, culinary and embroidery courses. She cared about women and she endeavored for them to have piecework to do. She was a member of the KGW in [name of the community] and then she was the chairwoman of the Group. [A3]

\footnotetext{
22 See the definition of ethics according to Max Weber (2011) and Maria Ossowska (2020).

23 ‘Koło Gospodyń Wiejskich’ [Rural Women’s Group].
}

Sometimes, inheriting social activity does not refer to activity in a particular local organization or team, but is manifested by the passions or talents of artistically-gifted family members:

My daughter also sings, plays, and dances. [...] On the one hand, that pains me because I know that that work is not profitable. [laughter] On the other hand, it is genuinely beautiful. As that is, after all, human development. A person devoid of culture is merely half a person to me. [A2]

In this article, we have employed the voluminous category of social activity. We define it - using Weber's conceptual framework - as an "action that according to the intentional sense of the agent refers to the behavior of others and is thereby oriented in its course" (Weber 2002:6). Therefore, we are operating within the area of the sociological theory of action for the good of others, rooted in the collective context (Nowak 2015). Among the four types of action distinguished by Max Weber-namely: rational action on account of purpose, rational action on account of values, affective actions, and traditional actions - the activities undertaken by local leaders reflected by the statements made by the research participants belong to more than one type of action. Above all, we interpret them as rational actions on account of values. Here, we are thinking about activities aimed at preserving the memory of certain persons and events, and upholding local traditions or encouraging local artistic groups to act. In the statements made by the animators - including those referring to shortfalls or emptiness - one can also identify the leaven of affective actions.

One of the female research participants is also an instructor for a local folklore group historically connected to her family. The social activity of her family is precisely what had shaped her adult life: 
I am involved in the Troupe's life, because I have been participating in it since my childhood. As a 3-year-old girl I was prepped by my grandmother and my mother to appear in local performances. You can say that I have grown into this culture and now I have a need to continue what my grandmother had started. It is certainly thanks to the fact that she inculcated that passion in me that today I am where I am and I like doing it [...]. I completed a two-year-long course to become an instructor of regional groups and this helps me in my work with the Troupe. [A3]

The history of this female animator is not an isolated case. Here, one should explicitly state that the key importance for the emergence of a future animator may stem from his/her family environment:

I completed a local-government administration school [...]. That local government was always of interest to me. I joined a family that also operated in the local government, it [has - R.W.] traditions and I have to see that [this - R.W.] is how things started. I went to attend a rural meeting with my father-in-law. He was the local village superintendent and he did not want to continue serving in this capacity because of his age, especially when he looked around and saw computerization, one knows those projects, we are members of the European Union and here I am as a newly acquired family member who would run and would be capable of running all of that. [A6]

An intensive exchange of experience leading to the acquisition of new competences can also sometimes take place within animators' families. At times, the flow of skills also takes place between active members of the local community:

[...] Husband who deals with a form of promotion taught me to be active in promotion. Because that is not easy. [...] He gave me the basics, he showed me how it is done, and he gave me some ideas. Without the support of the family, nothing can be done. [A2]

However, zeal and having the appropriate family support would not produce any effect without an individual being deeply rooted in the local community. Persons associated with a given community since birth, or long-term residents in a given area, are the named animators the most frequently:

My integration with the local community [name of the community], I have been living here for 62 years, it started when I was 9 years old, I think, and it has lasted to the present day. [...] My mom bought me a Bambino record player and a few records at the same time [...]. There was one television set in our village at that time and it was owned by one of the farmers. It was usually there on Saturdays or Sundays that we would meet for film screenings. There was also a children's club in the village where the youth would congregate in the evenings. Sometimes a mobile cinema would arrive, and usually on Saturdays an accordion player would show up to play as best he could and it was good fun. After one such open-air concert I was hired out along with my record player and records to the children's club for a dance. So one guy carried the record player and the records and one guy carried me piggyback. I sat at the table with my record player and I played everything as it came out, Hungarian, German, Polish, and then things started all over again. It was a grand party. I was supposed to be carried home by 8 p.m. but the party was such a great time that ultimately my dad came to intervene, but after imbibing several hefty drinks, his intervention proved to be ineffective, but then my mom thought that things were taking too much time, and she came to collect her young musician, and then no negotiations were admissible. [...] There were many such dances, but they ended before 8 p.m., I would go 
home, and the rest would stay behind to play cards, checkers or simply talk with one another; they also had dates, things were merry, and that's how I became part of the community which surrounds me to this day; on account of all of these years it has become one big family to me. The time came when what is known as the RUCH clubs were established and my young one was the manager of that club for many years, and then I was in the club every day. [A5]

The commitment demonstrated by the male and female animators in their work to benefit the well-being of the local community would not ordinarily be possible if it were not for the attitude of openness to others and drawing satisfaction from fulfilling their function. In nearly all of the interviews with the participants, it was noted that on top of the vocational work they perform (related to cultural animation), they devote at least several hours a week to activities related to the local community:

It would be difficult to count the number of hours devoted to activity, because that is not something that is countable for me. Every day [there is - R.W.] the Senior+ home for at least three hours, plus an additional two hours on Monday, Tuesday, and Thursday, and participation in the [name] choir's practice sessions for three hours. [A1]

The animators participating in the research are well-known in their local environment. This is evidenced at the very least by the fact that they were identified as leaders by representatives of the local institutions. Since in the past they had completed the tasks entrusted to them many times, they have also gained great social trust:

[The name of the river] flows through a historical park that has been beautifully revitalized, the park also houses a historical castle from the 12th century, private owner. We have a permit to use the castle. Many things take place there. The owner [first name] gave me the keys and said, Mr. [first name], please do what you like just as long as you don't burn the joint down. [A5]

The participants usually do not glean any financial benefits from their animation activities and they also sacrifice their leisure time. This is why one can say that a culture animator is chiefly a social role, not a professional role.

\section{Pictures as a testament to animators' commitment}

As access to digital techniques becomes more widespread, the trend of using pictures or video clips as source material in research has become more pronounced. Researchers came to widely recognize visual material as a valuable source of primary data. Some scientists even state that "some contemporarily important research problems may be explained in full only by using such 'soft methods'"' (Żuchowska-Zimnal 2013:100).

In the project discussed in this article, we have secured a small representation of visual materials (47 pictures and 6 video-clip recordings of several minutes in length). This is also the reason why we did not choose to interpret these photographs as part of visual sociology, or to discover hidden meanings and sense (Stańczak 2007; Konecki 2012). Nonetheless, hybrid ethnography facilitates the compilation and analysis of visual materials. When designing the research, we included elements of the sociology of pictures (Olechnicki 1999), recognizing that visual techniques - although they have many meanings and are difficult to interpret - are the best at painting the picture on the daily activities of cul- 
ture animators. In the obtained visual material, we looked for illustrations of the animators' activities described in the article, and of scenes showing the local dimension of their work. We perused the pictures constituting a testimony of the animators' direct commitment to coordinating events, which depicted the work done in the "background" of these projects and revealed their contribution, which is not obvious to the majority of the residents of a given community. These collages provide examples of the animators' activities during cultural events (Photograph 1) and their day-to-day work for local communities (Photograph 2). ${ }^{24}$

\section{Photograph 1. Animators at work for the local community}
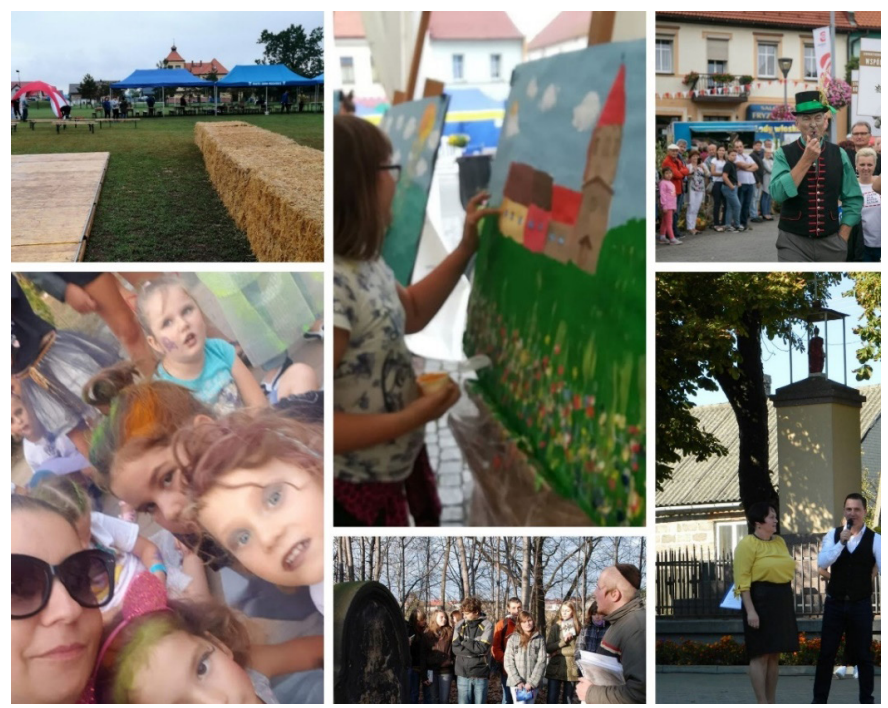

Source: proprietary material - photographs provided by the culture animators participating in the research

\footnotetext{
${ }^{24}$ In his 2011 article, Tomasz Ferenc points out that English-language literature uses the terms 'visual anthropology' and 'visual sociology', which - when translated into Polish - fail to fully convey the underlying sense of these disciplines. In this author's opinion, at present, i.e. in the day and age of audio-visuality, visual culture forms the principal field of interest in visual sociology and anthropology. That is also why the Polish terms proposed by Krzysztof Olechnicki (1999), namely "socjologia obrazu" and "antropologia obrazu," appear to be more suitable.
}

\section{Photograph 2. Preparations for local cultural events}

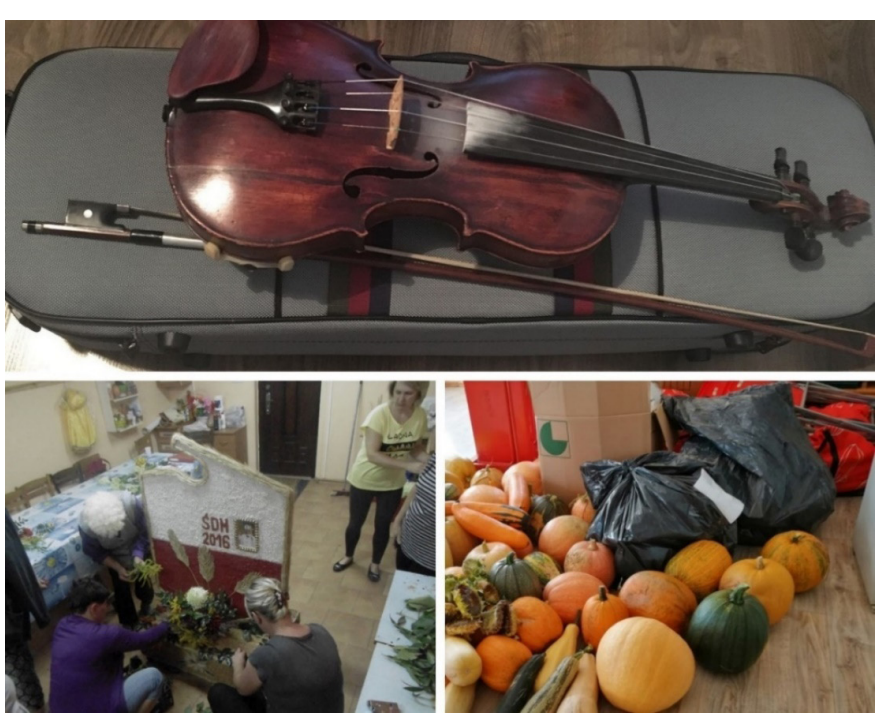

Source: proprietary material - photographs provided by the culture animators participating in the research

\section{Mapping the activity of local animators}

A relatively new element in sociological analyses is geolocation of individuals using GPS, followed by mapping their movements (Krzysztofek and Bomba 2011). Research employing geolocation is conducted in logistics, transport, or geography (information and planning) (Voilmy, Smoreda, and Ziemlicki 2008; Šveda and Madajová 2015). In the social sciences, geolocation research is used e.g. to analyze the movements of participants in protests and demonstrations (Rodríguez-Amat and Brantner 2016). Here, it is noteworthy that the 19th-century social researcher Charles Booth had already employed maps to depict the areas of wealth and poverty in the vicinity of London (Bales 1994). His work exerted a significant impact on the development of research methods in sociology. In this approach, a map was used to visualize data; it was 
supposed to facilitate the process of grasping the data. The sources for conceiving of this function can be traced back to the 17th-century Cartesian idea in which space was a "vessel" filled with objects, persons, or phenomena (Poczykowski 2006; see also Wiśniewski 2012:156-158). ${ }^{25}$ Mapping problem areas in the city was also a tool used in the work done by sociologists belonging to the Chicago School. Edward Hall (1976) as well as Derek Gregory and John Urry (1985) were developing more and more new themes over time in the sociology of space initiated by Georg Simmel in 1908 (1997); contemporarily, Martin G. Fuller and Martina Löw (2017) are among those who merit attention. For some time now, people have been reflecting on the new opportunities which new technologies have contributed to social research into space (Logan 2012). In the maps presented in this article, we have concentrated on accurately rendering the spatial activity of the persons. For this purpose, we have used the geolocation data provided by the culture animators participating in our research. Based on this, we construed maps depict-

\footnotetext{
${ }^{25}$ Contemporarily, many publications are devoted to slightly different aspects of perceiving space -, creating mental maps or the supporting technique of photographic walks (see Nóżka and Martini 2015:34-50). In turn, in the book titled Socjologia przestrzeni [The Sociology of Space] written by Martina Löw (2000 and 2018), space appears as a complicated and dynamic structure undergoing incessant change. As Marta Bucholc relates, "(There is] not only space as such, but rather the processes of constituting or forming space. Thus, the assumption is that we are dealing with a dynamic, process-related, syncretic and (in the broadest sense) constructionist approach. However, what is considerably more important is the relationary approach. On the one hand, therefore, the author opposes visions of space which she calls 'absolutistic', in which space is grasped as inflexible, an empty receptacle for things. Instead, she proposes thinking about space in terms of a system or order of living bodies and social goods that maintain certain relationships with one another" (2018:17). In this theory presented by the German sociologist, people are not the only ones to shape space. They are also joined by institutions, things, and even certain symbols. She does not directly present the hypothesis regarding the causality of inhuman factors, contrary to what Bruno Latour (2010) did; nevertheless, she does expand thinking about relationships.
}

ing the persons' movement and we superimposed on that information regarding the type of activities performed as well as their sequence. It should be emphasized that by applying elements of spatial analysis, we scrutinized the distribution of the institutions with which the local leaders participating in the research collaborate, and the reciprocal relations they have fostered in this capacity. The data created by the local animators has been used to carry out an intersubjective verification aimed at searching for the possibility of generalizing the schematics for their activity or comprehending their motivation to work for the local community.

In the analysis of the maps, we focused on recreating the network of links (relations) tying the local male and female leaders of culture with the specific venues, as well as their daily activity measured by the number of traveled kilometers, ${ }^{26}$ and the potential recurrence of those behaviors.

At the same time, it should be underlined that the participants retraced their activities and meetings with other people on their own. For them to be able to carry out that task accurately, we equipped them with the FlyBlog platform, which is customized to input geographical data. By collecting that information in a single location, it was possible to identify the key spots of the animators' daily activity. At the same time, we could identify the interrelated points as well as those which were bypassed or isolated. We have marked the visualization with information regarding the intensity of these relations, the dates of contact, the distance covered, and the variety of activities performed in a given venue. The maps presented below illus-

\footnotetext{
${ }^{26}$ We estimated the number of kilometers traveled in a straight line.
} 
trate the weekly activity of two female leaders who stood out from the rest of the respondents in terms of their relatively extensive spatial activity. At the same time, since the persons who shared their data covered large distances, they exemplify scalability-related problems. They depict the compromise stemming from the equilibrium between precision and the holistic nature of data.

\section{Map 1. The weekly activity of Animator 2}

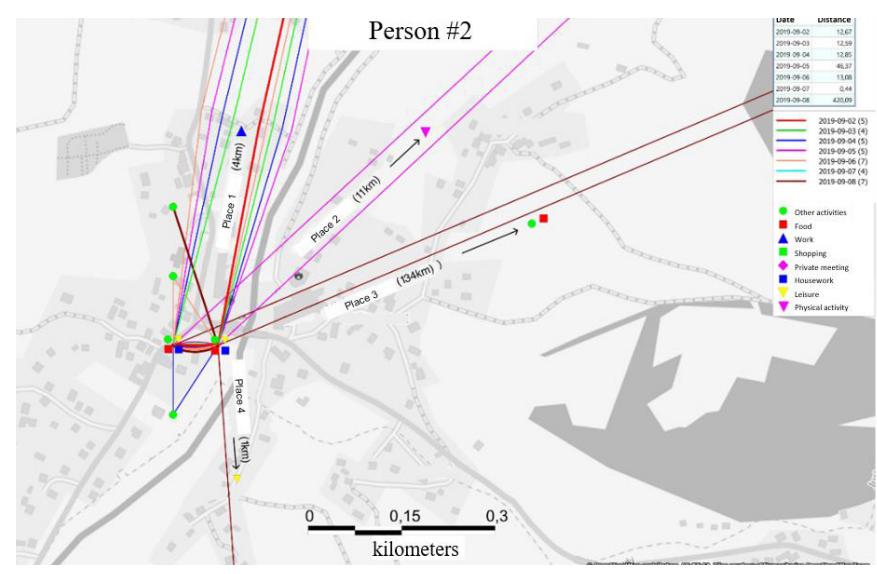

Source: Vectoss on the basis of data collected through diary research

\section{Map 2. The weekly activity of Animator 6}

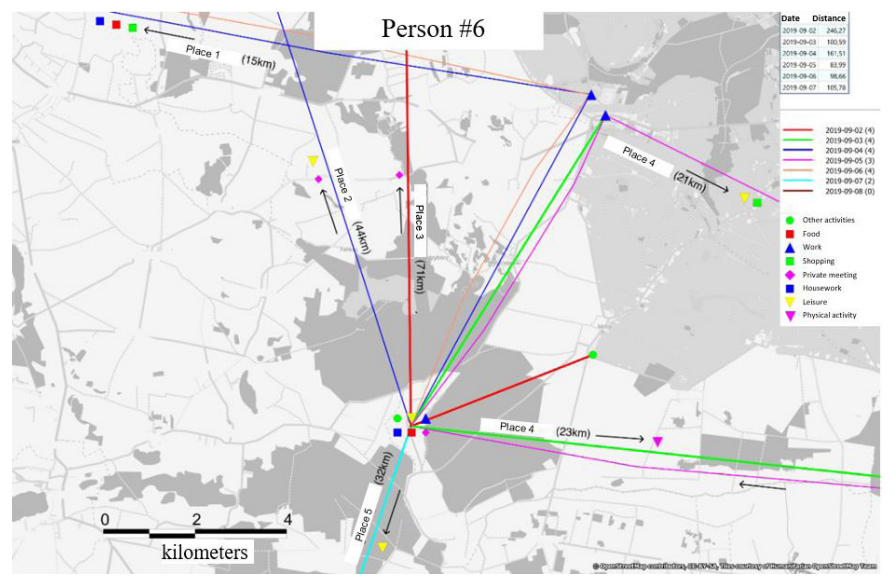

Source: Vectoss on the basis of data collected through diary research
Six local animators from five different communes reported their entire weekly activities. Persons at different ages, of different genders, and originating from different regions from around Poland mapped their activities. The geolocation data obtained from the participants - when superimposed on maps makes it possible to formulate some reflections regarding the respondents' spatial activity:

- Animators usually perform their vocational work in many locations. Five out of the six persons performed their business duties during the week in at least three different locations. These persons are mobile and capable of acting efficiently and flexibly, and they frequently change the place where their activities are undertaken.

- Vocational work strongly penetrates the work they do socially as well as their household duties. Four out of the six participants performed some of their vocational activities as well as their household tasks and spent their leisure time in one venue. When examining the compiled spatial data in the context of the animators' other statements, this can evidence their flexibility, great work motivation, and organizational skills. It should be stressed that this research material was compiled in 2019, i.e. prior to the outbreak of the COVID-19 pandemic, so remote work was not commonly available as a form of carrying out professional duties.

- Four persons had at least one social meeting during the week. These meetings were usually held with many people in attendance and were different in character, including e.g. family BBQs, canoe trips, and funeral ceremonies. Some of these activities were socially beneficial and involved helping others. The remarks re- 
corded by the participants reporting some of their calls in their journals are a testimony to this aspect: "Taking a walk with a lady friend and helping her get home (she uses a cane)" [A1]. Thus, these were (at least partly) rational actions on account of the values attached by the persons.

- Activity measured by the number of traveled kilometers varies greatly, both when one looks at the activity of a single person on various days and when one considers the weekly data of all of the interviewee. Within a week, the research participants traveled between 130 and $800 \mathrm{ki}-$ lometers. During this time, they visited from 4 to 10 different sites. It would be difficult to identify uniform patterns of activity among the persons based on these places. Only the way in which two people move about can be described as constant, meaning that their movements oscillate between several permanent points. Additionally, the average number of kilometers traveled by these participants was lower than that of the persons who had different routes with no clear daily pattern. Nor did we observe any impact exerted by variables depicting a commune's activity. A female animator from a commune characterized by its high level of activity and high budget (category 4) demonstrated the lowest spatial dynamism, as well as one from a commune for which there was no data available concerning the activity and budget, and in whose area no cultural center was operating (category 6). The differences did not ensue from the nature of the vocational work. This is evidenced by the fact that two of the female animators taking part in the research both of them serving as directors of their cultural centers - had an extremely different level of spatial dynamism. Therefore, one can surmise that the activity of female and male leaders is highly heterogenous and that it strongly hinges on a commune's calendar of events. One of the things that points to this is the fact that each one of the persons completing the journal spent a portion of his/her leisure time preparing for the cultural events scheduled in a given commune.

- The centers of these communities were the main area where the professional animators participating in the research were active. This area is usually where institutions of culture, schools, commune offices, and churches can be found, and the institutions, whose field of operation was where the animators carried out their professional duties. The place of residence of the animators exhibits the greatest multi-functionality; this is where they perform some of the professional duties, but also where they spend their leisure time and where they do their household chores.

- Private meetings were treated as a separate category in this analysis. These meetings (on top of professional work) were the reason for covering the largest number of kilometers, which can evidence the participants' great commitment to cultivate relationships with other persons.

The spatial analyses made it possible to affirm the respondents' declarations behaviorally. The ensuing portrait depicts people who are mobile and can perform the duties entrusted to them under varying infrastructural conditions and at different times of the day. The environmental determinants and the spatial layout of the community both appear to be 
of significance. However, the theme surrounding the impact exerted by space and the available infrastructure on the activity of local leaders does call for lengthier and perhaps more automated analyses. On the basis of the compiled research material, we have concluded that the time of observation envisaged by the research was too brief for us to gain a grasp on possible regularities in the animators' spatial activity. The observations should be longer and last at least two or three weeks. This conclusion might also serve as an indication for other researchers who will choose to delve into the topic of the activity of local culture animators.

\section{Conclusion}

The presented forms of autoethnography were helpful in recreating the characteristic elements of the activity of local culture animators. The method of structured diaries enriched with visual and geolocation elements offers a number of new interpretative possibilities. It is also attractive to the participants of the research themselves, as evidenced by the precision of the geolocation indications and the variety of the visual materials provided. ${ }^{27}$ However, the method of data delivery can arouse some doubts, as it depends on the participants responding to the diary method. The dates of conveying various batches of material might testify to some of the people filling out their diaries in an unsystematic manner. This may have resulted partly from technical difficulties or from the level of digital competences demonstrated by individual participants, but there are many elements that suggest that motivation and conscientiousness were both of significance, too. The high commitment

\footnotetext{
${ }^{27}$ This article focuses on the project's methodological assumptions and the opportunities for utilizing geolocation data in the analysis. The other visual materials (photos and video recordings) were used in the main publication (Wiśniewski et al. 2021).
}

shown by the animators in preparing local cultural events had a positive impact on the quality of data. Despite the utilization of multimedia elements and the transfer of the diary into the Internet, we did not manage to entirely eliminate the doubts concerning the level of research participants' engagement. Above all, the fact that some people reported their activity in an unsystematic manner revealed reservations, and this might have translated into a less detailed reproduction of the events of a given day. On the other hand, the advantage offered by online diaries comes from the fact that they provide knowledge about the delays experienced by particular persons.

Even though the core of the article pertains to methodological issues, we did succumb to the temptation of presenting preliminary analyses in the text. One fact deserves attention, namely that the family environment appears to be the factor driving an individual to become a local leader to the largest extent, and, to put it more precisely, the question of other family members being actively involved in work to benefit the local community. The theme of inheriting from grandparents, parents or parents-in-law a feeling of having certain commitments to the local community emerged in several interviews. On top of some of the elements conveyed in the process of primary socialization, the skillful utilization of a commune's permanent resources and the diligently construed informal contact network are both of importance. The creativity of local animators and the motivations associated with the inherited social activity prevent others from seeing the value of their work. Their commitment is often seen as something obvious. The dearth of support from members of the local community can lead to a lack of appreciation for the work done by local leaders and, as a consequence, to their diminished motivation to work for others. 


\section{References}

Bales Kevin 1994. Early innovations in social research: the Poverty Survey of Charles Booth (PhD). London School of Economics.

Becker, Howard S. and James Carper. 1956. "The Development of Identification with an Occupation." The American Journal of Sociology 61:289-298.

Blau Peter M. 1964. Exchange and Power in Social Life New York: Wiley.

Bucholc, Marta. 2018. Miejsce poza pojemnikiem. Wstęp do polskiego wydania Socjologii przestrzeni Martiny Löw. Warsaw: University of Warsaw Press.

Cialdini, Robert. 1995. Wywieranie wptywu na ludzi: teoria i praktyka. Gdansk: Gdańskie Wydawnictwo Psychologiczne.

Domecka, Markieta and Adam Mrozowicki. 2008. “Robotnicy i ludzie biznesu. Wzory karier zawodowych a zmiana społeczna in Poland." Przeglad Socjologii Jakościowej 4(1):136-155.

Dudkiewicz, Magdalena and Marek Dudkiewicz. 2017. Raport $z$ badania liderów kultury w subregionie radomskim. Warsaw: Fundacja Obserwatorium.

Fatyga, Barbara. 2014. "Cultural animator [Animator kultury]." In Słownik Teorii Żywej Kultury. Retrieved September 15, 2020 (http://ozkultura.pl/wpis/2800/5).

Ferenc, Tomasz. 2001. "Socjologia obrazu, socjologia fotografii - praktyki badawcze." Przeglad Socjologiczny/ Sociological Review 50(2):81-99.

Fuller, Martin G. and Martina Löw. 2017. "Introduction: An invitation to spatial sociology." Pp. 469-491 in Current Sociology Monograph 4/65. Sage.

Gibson, Barbara et al. 2013. "The Integrated Use of Audio Diaries, Photography, and Interviews in Research with Disabled Young Men." International Journal of Qualitative Methods 12(1):382-402.

Godlewski, Grzegorz et al. 2002. Animacja Kultury. Doświadczenie i przyszłość. Warsaw: Institute of Polish Culture at the University of Warsaw.

Goffman, Erving. 1961. Asylums. Essays on the Social Situation of Mental Patients and Other Inmates. New York: Anchor Books.
Gregory, Derek and John Urry, eds. 1985. Social Relations and Spatial Structures. London: Macmillan.

Hall, Edward. 1976. Ukryty wymiar. Warsaw: Wydawnictwo PIW.

Homans, George. 1967. The nature of social science, New York.

Hughes, Everett C. 1958. Men and their work. Toronto: Glencoe, Ill.: Free Press.

Konecki, Krzysztof. 1988. "Praca w koncepcji socjologii interakcjonistycznej." Studia Socjologiczne 1/1988:225-245.

Konecki, Krzysztof. 2012. "Wizualna teoria ugruntowana. Podstawowe zasady i procedury." Przegląd Socjologii Jakościowej 8(1):12-45.

Kozinets, Robert. 2006. “Netnography 2.0.” Pp. 129-142 in Handbook of Qualitative Research Methods in Marketing, edited by R. Belk. Cheltenham, UN, Northampton, MA: Edward Elgar Publishing.

Krause, Ewa. 2012. Rozwój kariery zawodowej studentów. Konteksty $i$ dokonania. Bydgoszcz: Publishing House of the Kazimierz Wielki University.

Krzysztofek, Kazimierz and Radosław Bomba. 2011. “Będziemy żyć pod cyfrowym niebem...." Culture and History 19/2011. Retrieved March 11, 2021 (http://www.kulturaihistoria.umcs. lublin.pl/archives/2400).

Latour, Bruno. 2010. Splatajac na nowo to, co społeczne. Wprowadzenie do teorii aktora-sieci. Cracow: Universitas Publishing House.

Laughland, Andrew and Lia Kvavilashvili. 2018. "Should participants be left to their own devices? Comparing paper and smartphone diaries in psychological research." Journal of Applied Research in Memory and Cognition 7(4):552-563.

Logan, John R. 2012. "Making a Place for Space: Spatial Thinking in Social Science." Annual Review of Sociology 38:507-524.

Löw, Martina. 2018. Socjologia przestrzeni. Warsaw: Publishing House of the University of Warsaw.

Malinowski, Bronisław. 2007. Dziennik w ścisłym znaczeniu tego wyrazu. Warsaw: Wydawnictwo Literackie. 
Nowak, Marek. 2015. Teoria nieracjonalnego działania. Socjologiczne studium na temat wolontariatu $i$ społecznego aktywizmu. Poznan: Wydawnictwo UAM.

Nowosielski, Michał and Marek Nowak. 2008. Jak badać społeczeństwo obywatelskie? Doświadczenia praktyków. Poznan: Wydawnictwo UAM.

Nóżka, Marcjanna and Natalia Martini. 2015. “Metody mobilne i wizualne w praktyce badawczej: zastosowanie fotospaceru w socjologicznych badaniach map mentalnych i zachowań terytorialnych ludzi." Przeglad Socjologii Jakościowej 11(4):34-50.

Olechnicki, Krzysztof. 1999. “Obraz i wizualność w naukach społecznych.” Kultura i społeczeństwo 3:39-71.

Ossowska, Maria. 2020. Ethos rycerski i jego odmiany. Warsaw: Wydawnictwo Naukowe PWN.

Pink, Sarah. 2008. "Walking with video." Visual Studies 22(3):240-252.

Poczykowski, Radosław. 2006. "Między socjologią a kartografią, czyli: mapa w głowie ER(R)GO." Teoria-LiteraturaKultura 2(13):9-21.

Przybylski, Liz 2020. Hybrid Etnography. Online, Offline, and in Between. Thousand Oaks: SAGE Publications.

Rodríguez-Amat, Joan R. and Cornelia Brantner. 2016. “Space and place matters: A tool for the analysis of geolocated and mapped protests." SAGE- new media and society 6(18):1027-1046.

Seim, Josh. 2019. Hybrid Ethnography: Mixing Participant Observation and Observant Participation. Speech at a conference American Sociological Association.
Simmel, Georg. 1997. “The sociology of space.” Pp. 137-170 in Simmel on Culture, edited by D. Frisby and M. Featherstone. London: SAGE.

Stage, Carsten, Bridgit Eriksson, and Camilla M. Reestorf. 2019. "Understanding cultural participation through participation - inventiveness, multivalence and epistemic modernization." Cultural Trends 1(29):19-34.

Stańczak, Gregory C., ed. 2007. Visual Research Methods Image, Society, and Representation. Thousand Oaks, New Delhi, London, Singapore: Sage Publications.

Šveda, Martin and Michala Madajová. 2015. “Merging diaries and GPS records: The method of data collection for spatio-temporal research." Moravian Geographical Reports 2(23):12-25.

Weber, Max. 2002. Gospodarka i społeczeństwo. Warsaw: PWN.

Weber, Max. 2011. Etyka protestancka i duch kapitalizmu. Warsaw: University of Warsaw Publishing House.

Voilmy, Dimitri, Zbigniew Smoreda, and Cezary Ziemlicki. 2008. "Geolocation and Video Ethnography: Capturing Mobile Internet used by a Commuter." Mobilities 3(2):201-222.

Wiśniewski, Rafał 2012. “W przestrzeni kultury i natury. Kilka uwag wstępnych o praktykach społecznych i świadomości ekologicznej." Politeja 20(2):155-169.

Wiśniewski, Rafał et al. 2021. Oswajając zmienność. Kultura lokalna z perspektywy domów kultury. Warsaw: National Centre for Culture.

Żuchowska-Zimnal, Gabriela. 2013. “Socjologia wizualna kluczem do (samo)poznania." Pótrocznik Nauka i Szkolnictwo Wyższe 1(41):100-116.

\section{Citation}

Wiśniewski, Rafał and Grażyna Pol. 2021. "Acting for the Local Community: Hybrid Ethnography in the Careers of Local Culture Animators." Przegląd Socjologii Jakościowej 17(3):164-183. Retrieved Month, Year (www.przegladsocjologiijakosciowej.org). DOI: https://doi.org/10.18778/1733-8069.17.3.09 


\title{
Działanie na rzecz społeczności lokalnej. Etnografia hybrydowa karier lokalnych animatorów kultury
}

\begin{abstract}
Abstrakt: Artykuł, skupia się na nowatorskiej metodologii, jaką wykorzystano do zbierania danych. Wskazujemy, w jaki sposób wykorzystaliśmy metodę dzienniczkową oraz jaki niesie ona z sobą potencjał analityczny. Sygnalizujemy również ograniczenia, które dostrzegliśmy w trakcie badania. Jednocześnie, by nie rezygnować zupełnie z dyskusji nad wnioskami z badania, odtwarzamy wybrane cechy wspólne w karierach zawodowych animatorów kultury. Do relacjonowania i interpretacji otaczającej ich rzeczywistości posłużyła nam hybrydalna metoda badania. Polegała ona na zastosowaniu dzienniczka, w którym badani opisywali fakty i zdarzenia z dnia poprzedniego, a dane o swojej lokalizacji nanosili na mape Google; notatki wzbogacali o krótkie eseje, materiał fotograficzny i filmowy. Następnie badani animatorzy wzięli udział w podsumowujących indywidualnych wywiadach pogłębionych. Rozważaniom nad użytecznością i innowacyjnością zastosowanych metod etnograficznych towarzyszy refleksja nad zróżnicowaniem doświadczeń animatorów kultury oraz czynnikami wpływającymi na ich zawodowe wybory.
\end{abstract}

Słowa kluczowe: animator kultury, metoda dzienniczkowa, etnografia hybrydowa, analiza przestrzenna, rola społeczna, kariera zawodowa 